\title{
The Path That a Turkish Preservice Teacher Follows: A Teaching Belief System Approach Including 'Self' ${ }^{1}$
}

\author{
Yrd. Doç. Dr. Eralp BAHÇiVAN* \\ Abant İzzet Baysal Üniversitesi, Eğitim Fakültesi, Bolu / Türkiye \\ Yrd. Doç. Dr. Bekir Kürşat DORUK \\ Abant İzzet Baysal Üniversitesi, Eğitim Fakültesi, Bolu / Türkiye \\ Yrd. Doç. Dr. İbrahim Alper KÖSE \\ Abant İzzet Baysal Üniversitesi, Eğitim Fakültesi, Bolu / Türkiye
}

\section{Abstract}

This study was conducted to examine the relationships among preservice teachers' beliefs about self, epistemological beliefs and conceptions about teaching and learning. For this purpose, a structural model was proposed based on the belief system approach of Rokeach (1968). Results of such a model have both theoretical and implicational contributions. To examine the proposed model, three different scales were utilized. A total of 918 Turkish preservice teachers participated in the study.

\footnotetext{
${ }^{1}$ This study is a part of Scientific Research Project supported by Abant Izzet Baysal University. Grant Number: 2014.02.04.797

* Sorumlu Yazar. Tel: +90 374254 1000/1653 E-posta: eralpbahcivan@ hotmail.com ORCID:0000-0001-5621-3302 (C) 2017 Kalem Eğitim ve Sağlık Hizmetleri Vakfi. Bütün Hakları Saklıdır. ISSN: 2146-5606
} 
Results showed that preservice teachers had three different types of self: autonomous, related and autonomous-related. If a preservice teacher had autonomous or autonomous-related self, s/he would have also sophisticated epistemological beliefs. Additionally, preservice teachers' sophisticated epistemological beliefs allowed them to hold more constructivist conceptions. Considering these results, some implications were presented in this paper.

Keywords: Belief system; Self; Epistemological beliefs; Conceptions of teaching and learning; Preservice teachers.

\title{
Fen Bilgisi Öğretmen Adaylarımızın Patikası: 'Benlik' Kavramını İçeren İnanç Sistemi Yaklaşımı
}

\begin{abstract}
$\ddot{\mathbf{O} z}$
$\mathrm{Bu}$ çalışmanın amacı öğretmen adaylarında benlik, epistemolojik inançlar ve öğrenme-öğretme anlayışları arasındaki ilişkilerin incelenmesidir. Bu amaç doğrultusunda Rokeach (1968) tarafindan ortaya konan inanç sistemi göz önünde bulundurularak yapısal bir model önerilmiştir. Böyle bir modelin sonuçlarının hem teorik hem de uygulama alanında katkılar sunacağına inanılmaktadır. Veri toplama amacıyla üç farklı ölçek kullanılmıştır. Çalışmanın örneklemi 918 öğretmen adayını kapsamaktadır. Çalışmanın sonuçlarına göre öğretmen adaylarında üç farklı benlik tipi gözlemlenmiştir: özerk, ilişkisel ve özerk-ilişkisel. Ayrıca, özerk ya da özerk-ilişkisel benliğe sahip adayların sofistike epistemolojik inançlara sahip olduğu görülmüştür. Bunun yanında öğretmen adaylarının sofistike epistemolojik inançlarının yapılandırmacı anlayışa sahip olmalarına sebep olduğu gözlemlenmiştir. Bu sonuçlar doğrultusunda uygulama önerileri çalışma içinde sunulmuştur.
\end{abstract}

Anahtar Kelimeler: İnanç sistemi; Benlik; Epistemolojik inanç; Öğrenme-öğretme anlayışı; Öğretmen adayları.

\section{Introduction}

The research has shown that teachers are effective on students' understanding and achievement (Abell, 2007). This reality motivates teacher educators, school administrators and policy makers to educate and train more qualified and efficient teachers. At this point, teachers' beliefs take researchers' attention since they affect teaching practices (Fives and Buehl, 
2012; Pajares, 1992). However, there may be countless of beliefs affecting teaching practices; therefore, determining hierarchies among these beliefs is necessary to educate qualified teachers (Rokeach, 1968).

Epistemological beliefs (Hofer and Pintrich, 1997) and conceptions of teaching and learning (Chan and Elliott, 2004) seem as parts of teaching belief systems of inservice or preservice teachers (PTs). In general, researchers expect that sophisticated epistemological beliefs provide PTs to hold constructivist conceptions of teaching and learning; however, there is substantial empirical evidence inconsistent with this expectation (e.g. Chan and Elliott, 2004). These unexpected results take researchers' attention to possible effects of cultural contexts on teaching beliefs such as on epistemological beliefs (Hofer, 2008).

Even though, some researchers offer that any psychological construction should be investigated by considering their contexts (answering where), developmental paths (answering how) and functionalities (answering why), psychology literature have (still) a Western vision; therefore, may ignore contextual differentiations (Kağıtçıbaşı, 2007). In this regard, teacher educators are in need of teaching belief systems including contextual variables. Also, variables (such as beliefs about self) empirically proved as differentiated considering cultural values can be placed into teaching belief systems for the same purpose. Considering this requirement, this study was conducted to present empirical evidences for existence of a comprehensive teaching belief system relating Turkish PTs' beliefs about self to their epistemological beliefs and conceptions about teaching and learning.

\section{Theoretical Framework}

\section{Belief Systems}

Fishbein and Ajzen (1975) define belief as a "person's subjective probability judgments concerning some discriminable aspects of his world; they deal with the person's understanding of himself and his environment" (p.131). These researchers also propose that beliefs should have a hierarchy to effect behavior. Rokeach (1968) states that people have countless of beliefs. He offers a belief system having a similar structure with atom by associating beliefs with particles of an atom. According to him, beliefs expand on a central-peripheral continuum in which central beliefs have more connections 
with other beliefs in comparison to peripheral ones, so central beliefs are more difficult to change and also shape peripheral beliefs.

Rokeach (1968) offers the five types of beliefs. Among them Types A and B beliefs relate to people's basic truths and nature of self. Type A beliefs base on a shared consensus with others whereas Type B beliefs involve zero consensus. Type $\mathrm{C}$ beliefs, also called as authority beliefs, correspond to beliefs about reference people helping an individual to make a realistic and rational picture of the world. Then, Type $\mathrm{D}$ beliefs include the beliefs derived from authorities similar to ideological beliefs. Finally, Type E beliefs are the ones representing (arbitrary) matters of taste. These beliefs have no durable connections with other beliefs in the system. According to Rokeach (1968), Type A and B beliefs are more central than Type C and D beliefs, because the former involve the beliefs related to self. Type $\mathrm{C}$ beliefs are also more central than Type D beliefs because the latter are derived from the former. Finally Type E beliefs are the most peripheral among all beliefs, because these beliefs have almost no connections or fewer connections with other beliefs.

\section{Self}

Self is defined as a socially constructed human model accepted by a culture (Heelas and Lock, 1981). Additionally, self covers an individual's awareness related to his/her perceptions about himself/herself (Kağıtçıbaş1, 2007). Cross cultural psychologists (e.g. Kağıtçıbaşı, 2007; Kitayama, Duffy and Uchida, 2007) accept that such a social construct is affected by cultural values such as collectivism and individualism. Two types of collectivism-individualism have been focused by researchers: normative (Hofstede, 1980; Triandis, 1995) and relational (Kağıtçıbaşı, 2007). The latter focuses on the independency or interdependency of the self. The underlying idea of the relational collectivism-individualism is that if a society presents individualistic values more than collectivistic values, independency gain importance in such a society. As a result, autonomous (independent) self is observed more than related (interdependent) self in such societies. Self is firstly defined by the western psychologists who proclaim individualistic values more than collectivist ones, so the autonomous self is highly praised at the beginning (Kağıtçıbaşı, 2007). But this dualistic (autonomous/related self) paradigm is being criticized by Kağıtçıbaşı $(1996,2007)$ who offers three different forms of self: autonomous, related and autonomous-related. Autonomous self is 
observed on people who are self-sufficient and separated from others in terms of societal relations. On the other hand, related self has transitional borders. Cross-cultural research studies support the idea that an individual may present characteristics of both autonomous and related self, therefore, Kağıtçıbaşı $(1996,2007)$ has defined a third category of self which is autonomous-related self. People who has autonomous-related self can take their decisions independently but also can have (close) relations with others (Kağıtçıbaşı, 2007; Kağıtçıbaşı and Cemalcılar, 2014).

Why the concept of self has been tackled by (cross-cultural) psychologists for years can be explained by its observed effects on people's ideas, emotions and behaviours (Kağıtçıbaşı and Cemalcılar, 2014; Kitayama, Duffy and Uchida, 2007). Self enhancement and achievement motivation can be given as examples. Autonomous people, in general, have a more robust tendency to self enhancement in comparison to related people. Additionally, autonomous people seem to have more personal achievement motivation than related people. However, such a differentiation may be observed because of the measurement approach. If measurements attach more value on societal effort instead of personal effort, then related people may present more achievement motivation (Kağıtçıbaşı, 2007).

\section{Epistemological Beliefs}

Personal epistemology refers to people's beliefs about structures of knowledge (e.g. certainty and simplicity) and knowing (e.g. source and justification) (Hofer and Pintrich, 1997). There are three main traditions in this research area. First tradition emerged with the seminal works of Perry (1970) whose tradition is called as developmental view. To this view, people initially have a dualistic status meaning that every knowledge is either right or wrong. Then, biological development (as in the Piagetian notion) triggers epistemological shifts stepping to multiplicity, relativism and commitment within relativism, respectively (Hofer and Pintrich, 1997). In the following years, Schommer (1994) has objected to this view and provided empirical evidences that people's epistemological beliefs can be more or less independent. Schommer (1994) has offered a belief system approach covering epistemological beliefs as dimensions of certainty, simplicity, source, quick learning and innate ability. The last two dimensions have been highly criticized because they relate to learning not to knowing. Schommer-Aikins (2004) has 
already accepted this critic. Among Schommer's dimensions certainty covers the beliefs about whether knowledge is absolute or evolving. Simplicity involves the beliefs about whether knowledge has isolated or interrelated bits. Finally, source dimension queries whether knowledge comes from authorities such as teachers, scientists and books. One of the critics about this belief system is that it does not involve justification as an independent dimension of personal epistemology. Schommer's belief system approach has started the idea that an individual may have sophisticated beliefs about simplicity of knowledge while unsophisticated (naive) stance about source of knowing. In spite of certain critics, Schommer's quantitative approach has provided researchers to relate personal epistemology to other constructs easier than before. Third tradition about personal epistemology is looking for whether people's epistemological beliefs have domain dependent character. In other words, the researchers in this tradition support the idea that people's epistemological beliefs have an unstable character if they are measured at specific tasks (Buehl, Alexander and Murphy, 2002; Hammer and Elby, 2002; Hofer, 2006). To illustrate, Palmer and Marra (2008) have showed that university students may have inconsistent epistemological beliefs across domains such as they may believe that knowledge in science is more certain the one in humanities. Productivity and contextual structures may also cause epistemological differentiation (Elby and Hammer, 2001). For example, a student may behave as s/he has unsophisticated beliefs to take higher grades although she has more sophisticated beliefs.

Why researchers have been interested in this construct can be explained by its connectedness with other constructs. Some researchers (e.g. Brownlee, Boulton-Lewis and Purdie, 2002; Hofer and Pintrich, 1997) state that epistemological beliefs (as central beliefs) affect the beliefs about learning and teaching (which are peripheral beliefs). Empirical evidences presenting epistemological beliefs effects on people's conceptions of teaching and learning (Chan and Elliott, 2004), self-regulated learning (Muis, 2007) and conceptual understanding (Bahçivan, 2015; Stathopoulou and Vosniadou, 2007) support this idea. Therefore, if possible, making shifts in people's epistemological beliefs means to intervene their learning and teaching behaviours. In this regard, education contexts seem to be effective on epistemological shifts (King and Kitchener, 2004). However, sophisticated epistemological beliefs do not always trigger desired behaviours or beliefs (Hofer, 2008). Such 
unexpected results take researchers' attention to importance of cultural contexts (Chan and Elliott, 2004; Hofer, 2008), social relationships (Bendixen and Rule, 2004; Schommer-Aikins, 2004) and self (Baxter-Magolda, 2004).

\section{Conceptions of Teaching and Learning}

The conceptions of teaching and learning can be defined as the beliefs held by (preservice) teachers about what learning is and how teaching should be (Chan and Elliott, 2004). Researchers (e.g. Bahçivan, 2014b; Marton, Dall'Alba and Beaty, 1993; Saljö, 1979; Tsai, 2004), via mostly phenomenographic studies, have revealed students'/PTs' conceptions of learning and labeled these conceptions by similar names such as memorizing, increase of knowledge, applying, etc... Certain researchers (e.g. Koballa, Graber, Coleman and Kemp, 2000; Tsai, 2002) have additionally explored preservice/inservice science teachers' conceptions of teaching and found similar categories such as transferring knowledge, interacting, process, etc... A critical analysis of research studies in this topic show that people's conceptions of teaching and learning can be categorized as traditional vs. constructivist in spite of existence of aforementioned labels (Chan and Elliott, 2004).

Furthermore, (preservice) science teachers have generally consistent conceptions of learning and teaching (Koballa et al., 2000; Tsai, 2002). In other words, a PT, holding constructivist conception of learning science, is expected to hold also constructivist conception of teaching science. Research studies prove that these conceptions relate to (preservice) teachers' teaching efficacy beliefs (Bahçivan, 2014a; Eren, 2009), pedagogical content knowledge (Bahçivan, 2014b) and teaching behaviours (Koballa, Glynn, Upson and Coleman, 2005). For example, a PT, holding sophisticated epistemological beliefs, most probably have constructivist conceptions of teaching and learning science. And, such a teacher may feel herself more efficacious in teaching science and behave in this expected manner in her future teaching practices.

\section{Proposed Model}

Considering the results and interpretations of aforementioned research studies, the proposed model was hypothesized as in Figure 1. This model attempts to clarify PTs' teaching belief system based on Rokeach's belief system approach which assumes that central beliefs affect the structure of 
peripheral beliefs. The proposed model includes three types of beliefs: beliefs about self, epistemological beliefs and beliefs about (conceptions of) teaching and learning. Each variable on the left side of the model are more central in according to the ones on the right side. Beliefs about self are associated with Types A and B beliefs; because, Rokeach (1968) already relates Types A and $\mathrm{B}$ beliefs to self. Then, epistemological beliefs in the model are accepted as Type C beliefs. Because, Rokeach (1968) calls Type C beliefs as authority beliefs helping an individual making a realistic and rational picture of the world. Such a description is consistent with the scope of epistemological beliefs. Finally, beliefs about teaching and learning are associated with Type $D$ beliefs, because these beliefs are derived from more central beliefs such as epistemological beliefs (Brownlee, Boulton-Lewis and Purdie, 2002; Hofer and Pintrich, 1997).

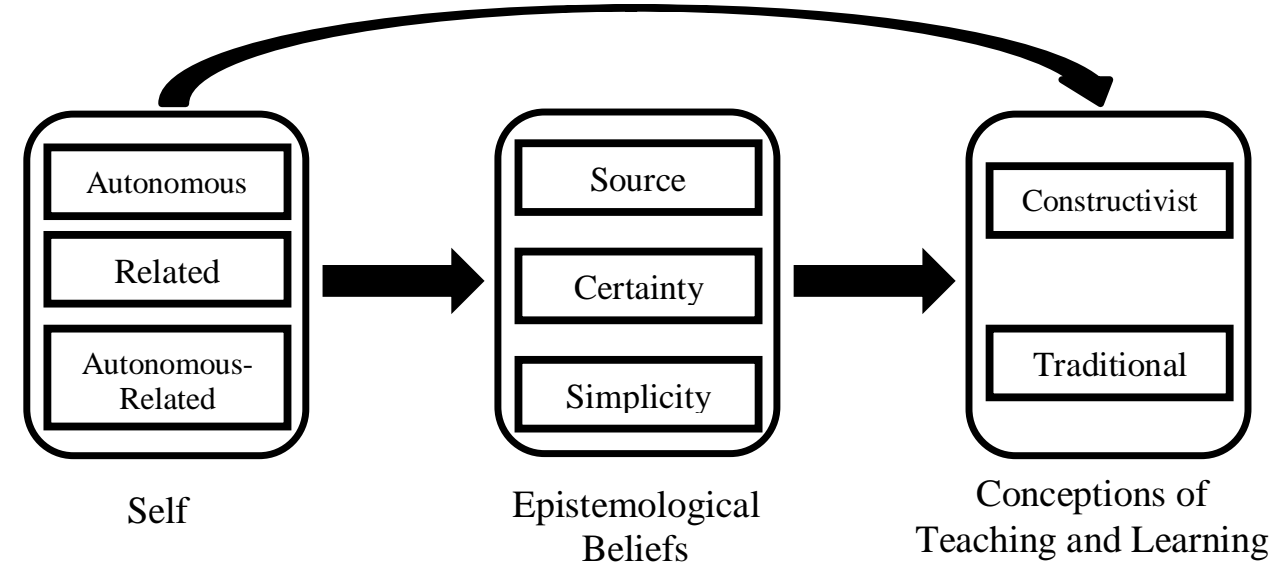

Figure 1. Proposed model of the study.

In summary, the model in Figure 1 proposes that PTs' beliefs about self shape their epistemological beliefs and conceptions about teaching and learning, and these epistemological beliefs also intervene in beliefs about teaching and learning. Hypothesized relationships were clarified below together with their reasons.

1) PTs having autonomous or autonomous-related self also hold sophisticated epistemological beliefs. Because, the autonomy that these people have provide them to take their own decisions even if they have close societal relationships with some others (Kağıtçıbaşı, 
2007). On the other hand, PTs having related self cannot take their own decision because their societal relations limit their autonomy so that these people are expected to have a more naive epistemological beliefs.

2) PTs having autonomous or autonomous-related self also have constructivist conceptions of teaching and learning. Because these PTs believe that people should have autonomy on their own learning, so these PTs may plan to teach considering individuals' autonomies. The reverse is expected for PTs having a related self.

3) PTs holding sophisticated epistemological beliefs have constructivist conceptions of teaching and learning, whereas PTs holding naive epistemological beliefs have traditional conceptions of teaching and learning. Both theoretical (e.g. Hofer and Pintrich, 1997) and empirical evidences (e.g. Bahçivan, 2014b) have already supported or expected such a relationship.

\section{Significance of the Study}

Examining the hypothesized relationships (see Figure 1) contributes to literature in terms of several respects. Firstly, this study may provide empirical evidences for PTs' teaching beliefs system. Especially, self (to the best of the authors' knowledge) has not been examined whether it is a part of PTs' teaching belief systems. Therefore, the first contribution of the study is theoretical. Secondly, possible relations examined in the study empower teacher educators' agenda in terms of how an ideal PT can be trained. For example, self education activities may be effective on PTs' epistemological beliefs and beliefs of teaching and learning. Finally, the results of this study have a potential to shed light on the confounding discussions about contextual dependency of epistemological beliefs. Some researchers (e.g. Chan and Elliott, 2004; Hofer, 2008) have focused on this issue underlying possible effects of culture on epistemological beliefs. In this study, PTs' beliefs about self (whose cultural roots was clarified above) would be examined in terms of their effects on PTs' teaching beliefs. Based on observed relations found in the study, following researchers will have empirical evidences about these confounding discussions.

\section{Purpose Statement and Research Questions}

The purpose of this study was to observe the connectedness among 
Turkish PTs' beliefs about self, epistemological belief and conceptions of teaching and learning. For this purpose, the following research questions were attempted to answer:

1. What are the relationships between Turkish PTs' beliefs about self and epistemological beliefs?

2. What are the relationships between Turkish PTs' beliefs about self and conceptions of teaching and learning?

3. What are the relationships between Turkish PTs' epistemological beliefs and conceptions of teaching and learning?

\section{Methodology}

\section{Sample}

A total of 918 PTs (249 male and 669 female) participated voluntarily in this study. Mean of PTs' age is 21 with a range of 19-36. The participants were selected from two universities (434 PTs and 484 PTs) at the central region of Turkey. The researchers attempted to reach a maximum number of participants from different departments by convenience sampling (Creswell, 2008). Sample included PTs from departments of primary education (190 PTs), science teaching (225 PTs), mathematics teaching (120 PTs), Turkish language teaching (145 PTs), technology teaching (127 PTs), special education (66 PTs) and psychological counselling and guidance (45 PTs). There were 538 junior PTs and 380 senior PTs in the sample. PTs were selected among junior and senior students because of two reasons. Firstly, these PTs are (in general) older than prior year PTs so that they are expected to hold more sophisticated epistemological beliefs. Secondly, the number of pedagogical courses that junior and senior PTs is higher than number that prior year students take, so that these PTs are expected to have more constructivist and established beliefs about teaching and learning. In summary, junior and senior PTs are expected to increase the possibility of significant relations among PTs' teaching beliefs.

\section{Instruments}

Data was collected through three different instruments: teaching and learning conceptions questionnaire (Chan and Elliott, 2004), epistemological beliefs questionnaire (Schommer, 1994) and autonomy and relatedness scales (Kağıtçıbaşı, Baydar and Cemalcılar, 2006). 


\section{Teaching and Learning Conceptions Questionnaire (TLCQ)}

Teaching and learning conceptions questionnaire (TLCQ) was developed and validated (Chan and Elliott, 2004) to determine preservice/inservice teachers' teaching and learning conceptions. TLCQ originally includes two factors: constructivist conception (e.g. Learning means students have ample opportunities to explore, discuss and express their ideas) and traditional conceptions (e.g. Learning means remembering what the teacher has taught). Constructivist conception composed of 12 items whereas traditional conception was represented by 18 items in TLCQ. Items were arranged in 5-point Likert scale ( $1=$ strongly disagree to $5=$ strongly agree) so that PTs getting high scores on constructivist items are the ones who hold constructivist conceptions. By constructivist conception, Chan and Elliott (2004) meant that "learning is the creation and acquisition of knowledge by the learner through reasoning, and justification. Teaching is a provision and facilitation of the learning process..." (p.821).

This instrument was firstly adapted into Turkish language by Eren (2009) who reported a good model fit $\left(\chi^{2} / \mathrm{df}=2.42\right.$; NNFI=.93; CFI=.94; RMSEA $=.061)$ and high reliability scores for constructivist $(\alpha=.92)$ and traditional $(\alpha=89)$ conception dimensions. In this study, a first order confirmatory factor analysis (whose results was presented in next division) was performed for validation $(n=918)$.

\section{Autonomy and Relatedness Scales (ARS)}

Autonomy and relatedness scales (ARS) was developed by Kağıtçıbaşı, Baydar and Cemalcilar (2006) in a study including Turkish university students. According to the initial reports provided by these researchers, ARS covers three different scales: autonomous self (e.g. I feel myself independent from my relatives), related self (e.g. My relatives have a priority in my life) and autonomous-related self (e.g. Both of having close relationships and being autonomous are important to me). Each scale included 9 items, which had a 5 point Likert scale ( $1=$ strongly disagree to $5=$ strongly agree). 6 items for autonomous self scale and 4 items for each of related self and autonomous-related self scales were recoded so that high scores meant that PTs have that type of self. Kağıtçıbaşı, Baydar and Cemalcılar (2006) reported reliability scores as $\alpha=.74, .78, .84$ respectively for autonomous self, related self and autonomous-related self scales. In this study, a first order confirmatory factor 
analysis was conducted for validation $(n=918)$.

\section{Epistemological Beliefs Questionnaire (EBQ)}

Epistemological beliefs questionnaire (EBQ) was developed by Schommer (1994) as including five dimensions, which were labeled as simple knowledge, certain knowledge, omniscient authority, innate ability and quick learning. The items of last two dimensions were not included in the study, because researchers (e.g. Schommer-Aikins, 2004) admit that these two dimensions relates to learning not to knowing. Each of three dimensions involved at least two subsets (hypothetical dimensions) covering 45 items in total. All the items of EBQ were translated into Turkish and factorial structure of the instrument has been evidenced by previous researchers (e.g. Y1lmaz-Tüzün and Topçu, 2008). In this study, to avoid fatigue, 9 items for simplicity (e.g. Most words have one clear meaning), 8 items for source (e.g. You can believe almost everything you read) and 5 items for certainty (e.g. Truth is unchanging) dimensions was selected by the researchers to measure Turkish PTs' epistemological beliefs. Items were presented in a 5 point Likert scale ( $1=$ strongly disagree to $5=$ strongly agree). Recoding procedure (in all dimensions) was made so that higher scores implied a naive epistemology, whereas lower scores implied a sophisticated epistemology. A first order factor analysis was conducted for validation $(n=918)$.

\section{Data Collection}

The questionnaires and scales were placed into a unique instrument, which included four parts. In the first part, PTs were requested to answer certain demographic statements such as gender, school, age and department. Following parts included the TLCQ, ARS and EBQ. Before the data collection, the instrument was approved by the Abant Izzet Baysal University Ethical Committee. Then, the instrument was distributed to PTs during their regular course time. They were informed about the purpose of the study and requested to respond the instrument. All the participants participated in the study voluntarily. During data collection any time limitation was not implemented. Average responding time for filling out the scales was approximately 30 minutes. After finishing the data collection, the researchers entered the data into SPSS. 


\section{Data Analysis}

Results included both descriptive and inferential statistics. Mean and standard deviations were examined in SPSS for descriptive results, which also comprised validation results. Confirmatory factor analysis was performed for validation purposes by AMOS. Also, the reliability scores were calculated by SPSS. Finally, a structural equation model analysis was conducted by AMOS to observe relations among PTs' beliefs about self, conceptions of teaching and learning and epistemological beliefs.

\section{Results}

\section{Descriptive Results}

\section{Validation of TLCQ}

A first order confirmatory factor analysis $(n=918)$ was performed on 30 items. In the first attempt, items 7, 9, 11 and 30 were excluded because their factor loadings (regression weights) were observed lower than 0.3. Second attempt confirmed that TLCQ had two factors: traditional (14 items) and constructivist (12 items) conceptions. Table 1 was prepared to display factor loadings (FL), means (M), standard deviations (SD) and reliability scores for each dimension $(\alpha)$.

All the items presented in Table 1 had factor loadings greater than 0.30 $(p<0.001)$. Certain fit indices were also examined to check fit of the data to the proposed confirmatory model. Chi-square value for per degree of freedom $\left(\chi^{2} / \mathrm{df}\right), \mathrm{CFI}, \mathrm{TLI}$ and RMSEA were observed as 2.86, 0.93, 0.92 and 0.04 which correspond to a good model fit. Finally, as can be seen in Table 1, the reliability scores were observed as 0.86 and 0.87 , respectively for constructivist and traditional conceptions.

According to mean scores in Table 1, PTs had higher mean scores in items of constructivist conception. Considering (higher) mean scores, it can be said that PTs believe that students' ideas, feelings and particular needs should be given attention and students should be directed to create their own answers by discussing and making hands on activities. On the other hand, in 7 items of traditional conception, PTs had mean scores higher than midpoint (2.50). Considering these items it can be said that PTs believe that a teacher should take students under control to provide them learning something as the authority. A teacher should transmit knowledge to students. Also, the students 
should remember what the teacher taught them. Finally, it is good news that PTs have lower SD scores in items of constructivist conception than traditional items. Therefore, PTs can be expected to have closer conceptions in constructivist conceptions in accordance to the traditional conceptions.

Table 1. Descriptive Results of TLCQ

\begin{tabular}{ccccc}
\hline Code $^{*}$ & FL & M & SD & A \\
\hline C1 & 0.50 & 4.62 & 0.77 & 0.86 \\
C2 & 0.46 & 4.53 & 0.79 & \\
C5 & 0.58 & 4.29 & 0.83 & \\
C6 & 0.58 & 4.36 & 0.89 & \\
C10 & 0.67 & 4.43 & 0.85 & \\
C13 & 0.67 & 4.43 & 0.93 & \\
C14 & 0.79 & 4.41 & 0.86 & \\
C18 & 0.48 & 4.01 & 0.87 & \\
C19 & 0.60 & 4.00 & 0.90 & \\
C24 & 0.47 & 4.00 & 0.94 & \\
C25 & 0.62 & 4.33 & 0.93 & \\
C28 & 0.46 & 4.09 & 0.99 & \\
T3 & 0.42 & 2.14 & 1.09 & 0.87 \\
T4 & 0.48 & 2.59 & 1.10 & \\
T8 & 0.62 & 2.13 & 1.17 & \\
T12 & 0.66 & 2.25 & 1.26 & \\
T15 & 0.30 & 3.40 & 1.08 & \\
T16 & 0.51 & 2.76 & 1.15 & \\
T17 & 0.71 & 2.28 & 1.21 & \\
T20 & 0.51 & 2.83 & 1.21 & \\
T21 & 0.68 & 2.22 & 1.12 & \\
T22 & 0.60 & 2.54 & 1.24 & \\
T23 & 0.59 & 2.61 & 1.27 & \\
T26 & 0.32 & 3.31 & 1.10 & \\
T27 & 0.72 & 2.31 & 1.22 & \\
T29 & 0.55 & 2.94 & 1.22 & \\
\hline
\end{tabular}

"Letters represent factors ( $\mathrm{C}$ for constructivist and $\mathrm{T}$ for traditional), numbers represent item rankings. 


\section{Validation of ARS}

Construct related evidence was presented with a confirmatory factor analysis. In the first attempt, items 3, 11, 12 and 22 were extracted (because of their low factor loading values), and then, the analysis was conducted again. Table 2 displayed the results of this validation. To the results, there were the three types of self labeled as autonomous self ( 8 items), related self ( 7 items) and autonomous-related self ( 8 items). Certain fit indices $\left(\chi^{2} / \mathrm{df}=3.33\right.$, $\mathrm{CFI}=0.91$, TLI $=0.88$ and RMSEA $=0.05$ ) supported that the model had an acceptable fit. Finally, Cronbach alphas were $0.68,0.67$ and 0.74 respectively for autonomous, related and autonomous-related self dimensions.

Table 2. Descriptive Results of ARS

\begin{tabular}{ccccc}
\hline Code $^{*}$ & FL & M & SD & $\boldsymbol{\alpha}$ \\
\hline A1 & 0.30 & 3.03 & 1.11 & 0.68 \\
A2 & 0.30 & 3.53 & 1.11 & \\
A4 & 0.52 & 3.29 & 1.12 & \\
A5 & 0.35 & 2.42 & 0.97 & \\
A6 & 0.45 & 2.24 & 0.91 & \\
A7 & 0.67 & 3.16 & 1.05 & \\
A8 & 0.67 & 2.99 & 1.07 & \\
A9 & 0.58 & 3.37 & 1.09 & \\
R10 & 0.58 & 3.90 & 0.96 & 0.67 \\
R13 & 0.32 & 3.51 & 1.04 & \\
R14 & 0.60 & 3.77 & 0.97 & \\
R15 & 0.45 & 3.43 & 1.20 & \\
R16 & 0.46 & 3.76 & 1.01 & \\
R17 & 0.77 & 3.98 & 0.96 & \\
R18 & 0.42 & 3.15 & 1.25 & \\
AR19 & 0.41 & 4.07 & 0.98 & 0.74 \\
AR20 & 0.60 & 4.25 & 0.97 & \\
AR21 & 0.35 & 3.11 & 1.20 & \\
AR23 & 0.42 & 3.44 & 1.26 & \\
AR24 & 0.33 & 3.17 & 1.20 & \\
AR25 & 0.55 & 3.72 & 1.06 & \\
AR26 & 0.57 & 3.37 & 1.22 & \\
AR27 & 0.54 & 4.10 & 1.03 & \\
\hline
\end{tabular}

* Letters represent factors (A for autonomous, $\mathrm{R}$ for related and AR for autonomous-related self), numbers represent item rankings. Bold coded items were recoded. 
Table 2 also displayed additional descriptive information. For example, mean scores in related to self items were obviously higher than the ones in autonomous self. These differences indicate that Turkish PTs give more weight to properties of relatedness in their self in comparison to autonomy. On the other hand, autonomous-related self items had higher mean scores than related self items. In summary, mean scores show that Turkish PTs have a tendency to experience relatedness and autonomy at the same time.

\section{Validation of EBQ}

A first order confirmatory factor model was examined for validation of EBQ results. Initial attempts resulted that any items in certainty dimension had not factor loading values higher than 0.15. All these five items were excluded and the model was examined again. At the end, EBQ included with two dimensions: source (6 items) and simplicity ( 7 items). Fit indices were examined as $\chi^{2} / \mathrm{df}=3.30, \mathrm{CFI}=0.94$, TLI=0.91 and RMSEA $=0.05$ which correspond to an acceptable fit. Table 3 showed that reliability scores were observed as 0.57 and 0.61 respectively for source and simplicity dimensions.

Table 3. Descriptive Results of EBQ

\begin{tabular}{ccccc}
\hline Code $^{*}$ & FL & M & SD & $\boldsymbol{\alpha}$ \\
\hline S1 & 0.54 & 2.43 & 1.27 & 0.57 \\
S3 & 0.62 & 2.24 & 1.20 & \\
S9 & 0.30 & 2.25 & 1.07 & \\
S13 & 0.59 & 2.71 & 1.26 & \\
S17 & 0.31 & 2.17 & 0.94 & \\
S21 & 0.32 & 2.03 & 0.85 & \\
Si1 & 0.76 & 2.24 & 0.92 & 0.61 \\
Si2 & 0.63 & 2.19 & 1.22 & \\
Si6 & 0.47 & 2.39 & 1.23 & \\
Si11 & 0.48 & 2.80 & 1.26 & \\
Si14 & 0.31 & 2.06 & 0.94 & \\
Si16 & 0.32 & 3.09 & 1.07 & \\
Si20 & 0.37 & 2.87 & 1.14 & \\
\hline
\end{tabular}

Letters represent factors ( $\mathrm{S}$ for source and $\mathrm{Si}$ for simplicity), numbers represent item rankings. Bold coded items were recoded.

According to Table 3, Turkish PTs' item mean scores were observed as close to midpoints. Considering that higher scores corresponded to naive 
epistemological beliefs, it can be said that Turkish PTs had slightly more sophisticated beliefs in source dimension than in simplicity dimension. When it comes to naive beliefs in source dimension, PTs seem to have a tendency not to suspect the authorities despite they do not understand anything coming from these authorities. Regarding the naive beliefs in simplicity dimension, PTs believe that scientific problems have one right answer and integration of knowledge should be avoided to prevent themselves from complicatedness.

\section{Relationships among Self, Epistemological Beliefs and Concepti- ons}

Relationships among PTs' self, epistemological beliefs and beliefs about teaching and learning were examined by structural equation modelling analysis. Structural (significant) relations were displayed in Figure 2. The model had an acceptable fit $\left(\chi^{2} / \mathrm{df}=1.92, \quad \mathrm{CFI}=0.91, \mathrm{TLI}=0.89\right.$ and RMSEA=0.03). The model explained variance of source, simplicity, constructivist and traditional conceptions as $98 \%, 84 \%, 33 \%$ and $69 \%$ respectively.

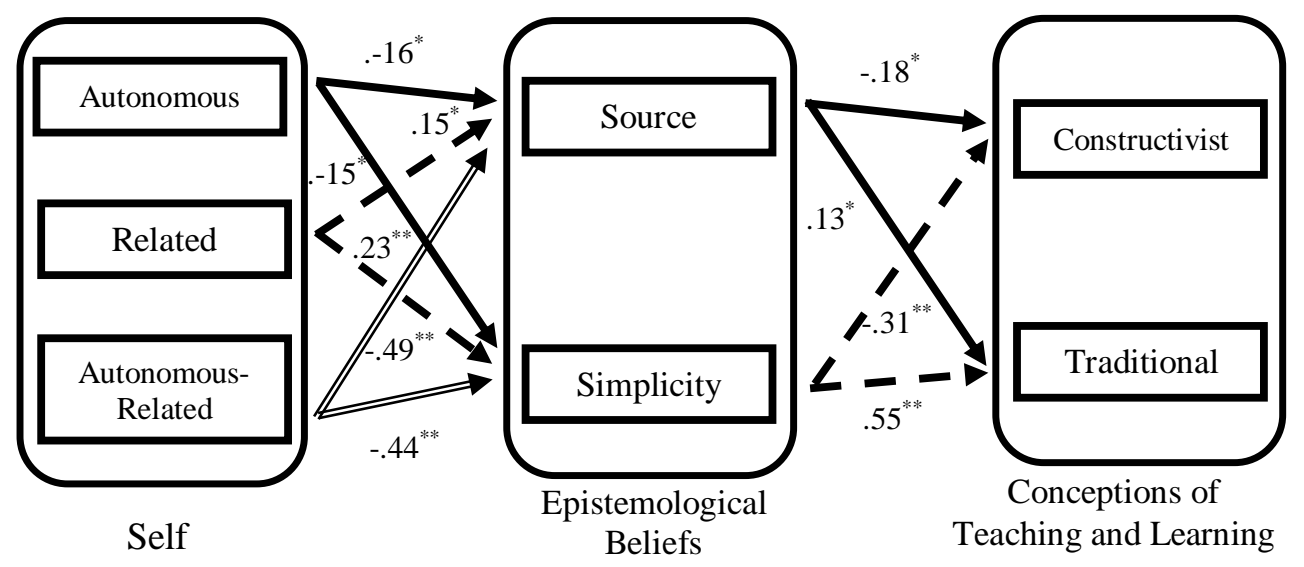

Figure 2. Observed relations in the proposed model $\left({ }^{*} p<0.01,{ }^{* *} p<0.001\right)$.

Figure 2 showed that most of the hypothesized relations between PTs' beliefs about self and epistemological beliefs was observed. For example, autonomous or autonomous-related self negatively predicted naive epistemological beliefs whereas related self positively predicted the same epistemological beliefs. In addition, PTs' naive epistemological beliefs negatively 
related to constructivist beliefs about teaching and learning whereas the relationship was observed as positive for traditional beliefs about teaching and learning. PTs' beliefs about self were not directly related to their beliefs about conceptions of teaching and learning. However, this unrelatedness is not coherent with the hypothesized relations presented at the beginning of the study.

\section{Discussions, Conclusions and Limitations}

The purpose of this study was to examine the structural relations among PTs' self, epistemological beliefs and conceptions of teaching and learning. For this purpose, belief system of Rokeach (1968) was used as the theoretical framework. Each of the latent variables was defined as a type of belief based on the literature and examined as a part of the model which included beliefs about self, epistemological beliefs and beliefs about teaching and learning respectively from more central to peripheral.

Autonomous and autonomous-related PTs are expected to have autonomy and to take their decisions based on this autonomy (Kağıtçıbaşı, 2007). This autonomy provides these PTs to gain independency which, at the end, can promote breaking people's connections to/respect for authorities (Kağıtçıbaşı, 2007; Kağıtçıbaşı and Cemalcılar, 2014). In the epistemology literature a plethora of research studies define such tendencies as epistemological sophistication (Hofer and Pintrich, 1997; King and Kitchener, 2004; Schommer, 1994). In this study, beliefs about autonomous and autonomous-related self were expected to negatively predict naive epistemological beliefs whereas related self were expected to positively predict the same epistemological beliefs. Considering the previous research studies, it can be said that this study has contributed to the literature by confirming these relationships. These findings also indirectly respond to researchers who call others to investigate possible effects of cultural contexts on epistemological beliefs (e.g. Chan and Elliott; 2004; Hofer, 2008, Schommer-Aikins, 2004). Because, beliefs about self already have been proved as directly shaped by cultural values and contexts (Kağıtçıbaşı, 2007; Kitayama, Duffy and Uchida, 2007). Also, the results showed that PTs' beliefs about autonomous-related self more strongly attached to their epistemological beliefs than autonomous and related self. This result needs further investigation but we speculate that it might be observed due to the cultural situation of Turkey. Turkey places 
on a geographical situation whose borders touch both west and east. This reality fosters Turkish society to present both types of self simultaneously. Therefore, in Turkish society a modern citizen should have both characteristics of self. Because of this situation, autonomous-related self may be more strongly related to epistemological beliefs than other types of self.

Furthermore, beliefs about self were expected to relate to beliefs about teaching and learning. Because, for example, related PTs consider their relations and/or (cultural) authorities in their decisions and learning (Kağıtçıbaşı, 2007). Such a relatedness may force them to hold traditional conceptions of teaching. In this regard, autonomous and autonomous-related PTs were also expected to hold constructivist conceptions about teaching and learning beliefs. However, these direct relations were not observed in this study.

As a final, naive epistemological beliefs were expected to negatively relate to constructivist teaching and learning beliefs; on the other hand, sophisticated epistemologies were expected to negatively relate to traditional teaching and learning beliefs because of two reasons. Firstly, some researchers (e.g. Brownlee, Boulton-Lewis and Purdie, 2002; Hofer and Pintrich, 1997) state that epistemological beliefs shape the beliefs about teaching and learning. Secondly, in epistemology literature many researchers (especially the ones having a developmental view) state that Piagetian notion foster epistemological sophistication (e.g. King and Kitchener, 2004; Perry, 1970). In this regard, this study confirmed these expected relations between epistemological beliefs and beliefs about teaching and learning. In addition, the results showed that PTs' beliefs about simplicity were more strongly related to their conceptions of teaching and learning in comparison to their beliefs about source. This result proves that PTs' simplicity beliefs may be more central than their source beliefs. In other words, there may be a hierarchy among the epistemological beliefs which should be investigated.

In summary, empirical evidences presented in this study partly approved what Rokeach (1968) expects. According to Rokeach central beliefs have more connections with relatively peripheral beliefs. However, beliefs about self had no direct relationship with beliefs about teaching and learning, but had a direct relationship with epistemological beliefs. Therefore, based on these findings, one can conclude that central beliefs may have not direct 
effect on all other relatively peripheral beliefs. Epistemological beliefs seemed to be mediators between beliefs about self and beliefs about teaching and learning. The researchers of the study called this mediated relation as the way of a PT that his/her beliefs about self determine his/her epistemological beliefs, which, at the end, shape his/her beliefs about teaching and learning.

There are three types of limitations of this study. Firstly, the data was collected through self reporting. The researchers have no direct observation regarding participants' self and epistemological beliefs. Secondly, EBQ was not validated to include certainty items. This instrument has already not included justification as a dimension. Therefore, two widely accepted dimensions of personal epistemology were not measured in this study. Finally, possible effects of cultural contexts were not directly observed but indirectly observed via 'self'.

\section{Implications}

Considering the results of this study, two different implications can be offered. First implication is suggested to teacher educators. Results of the study showed that an interdisciplinary approach has the potential to develop teacher educators' vision about the content of their work. We, as the researchers of this study, call following researcher to examine possibility of 'self education' in teacher certificate programs. Because results of this study showed that changes in PTs' beliefs about their self may affect how they teach their subject areas. Second implication is suggested to researchers: we still in need of more reliable and comprehensive measurements of personal epistemology. Following researchers should attempt to develop new questionnaires, which should not trigger fatigue.

\section{References}

Abell, S. K. (2007). Research on science teacher knowledge. In S. K. Abell, and N. G. Lederman, (Eds.), Handbook of research on science education (pp. 1105-1149). London: Lawrence Erlbaum Associates Publishers.

Bahçivan, E. (2014a). Examining relationships among Turkish pre-service science teachers' conceptions of teaching and learning, scientific 
epistemological beliefs and science teaching efficacy beliefs. Journal of Baltic Science Education, 13(6), 870-882.

Bahçivan, E. (2014b). Investigating coherence between preservice science teachers' conceptions of learning and teaching science: a phenomenographic study. Ahi Evran Üniversitesi Kırşehir Eğitim Fakültesi Dergisi, 15(3), 147-166.

Bahçivan, E. (2015). Exploring high school students' topic specific epistemologies and their impacts on conceptual understanding in the topic of force and motion: a structural equation study. Kastamonu University Education Journal, 23(3), 1107-1126.

Baxter-Magolda, M. B. (2004). A constructivist conceptualization of epistemological reflection. Educational Psychologist, 39(1), 31-42.

Bendixen, L. D. and Rule, D. C. (2004). An integrative approach to personal approach: A guiding model. Educational Psychologist, 39(1), 69-80.

Brownlee, J., Boulton-Lewis, G. and Purdie, N. (2002). Core beliefs about knowing and peripheral beliefs about learning: Developing an holistic conceptualisation of epistemological beliefs. Australian Journal of Educational \& Developmental Psychology, 2, 1-16.

Buehl, M. M., Alexander, P. A. and Murphy, P. K. (2002). Beliefs about schooled knowledge: Domain specific or domain general? Contemporary Educational Psychology, 27, 415-449.

Chan, K. W. and Elliott, R. G. (2004). Relational analysis of personal epistemology and conceptions about teaching and learning. Teaching and Teacher Education, 20(8), 817-831.

Creswell, J. W. (2008). Educational research: planning, conducting and evaluating quantitative and qualitative research. New Jersey: Pearson.

Elby, A. and Hammer, D. (2001). On the substance of a sophisticated epistemology. Issues and Trends, 85, 554-567. 
Eren, A. (2009). Examining the teacher efficacy and achievement goals as predictors of Turkish student teachers' conceptions about teaching and learning. Australian Journal of Teacher Education, 34(1), 69-87.

Fishbein, M. and Ajzen, I. (1975). Belief, attitude, intention and behaviour: An introduction to theory and research. Reading, MA: Addison-Wesley.

Fives, H. and Buehl, M. M. (2012). Spring cleaning for the "messy" construct of teachers' beliefs: What are they? Which have been examined? What can they tell us? In K. R. Harris, S. Graham, T. Urdan, S. Graham, J. M. Royer and M. Zeidner, (Eds.), APA educational psychology handbook: individual differences and cultural and contextual factors (pp. 471-499). Washington, DC: American Psychological Association.

Hammer, D. and Elby, A. (2002). On the form of a personal epistemology. In B. K. Hofer and P. R. Pintrich, (Eds.), Personal epistemology: The psychology of beliefs (pp. 169-190). London: Lawrence Erlbaum Associates Publishers.

Heelas, P. and Lock, A. (1981). Indigenous psychologies: The anthropology of the self. London: Academic Press.

Hofer, B. K. (2008). Personal epistemology and culture. In M. S. Khine, (Ed.), Knowing, knowledge and beliefs. Epistemological studies across diverse cultures (pp. 3-22). Dordrecht: Springer.

Hofer, B. K. (2006). Domain specificity of personal epistemology: resolved questions, persistent issues, new models. International Journal of Educational Research, 45, 85-95.

Hofer, B. K. and Pintrich, P. R. (1997). The development of epistemological theories: Beliefs about knowledge and knowing and their relation to learning. Review of Educational Research, 67, 88-140.

Hofstede, G. (1980). Culture's consequences: International differences in work-related values. Beverly Hills, CA: Sage. 
Kağıtçıbaşı, Ç. (1996). Özerk-ilişkisel benlik: Yeni bir sentez. Türk Psikoloji Dergisi, 11, 36-44.

Kağıtçıbaşı, Ç., Baydar, N. and Cemalcılar, Z. (2006). Autonomy and relatedness scales (Progress report). İstanbul: Koç Üniversitesi.

Kağıtçıbaşı, Ç. (2007). Family, self, and human development across cultures, theory and applications $\left(2^{\text {nd }}\right.$ ed.). London: Lawrence Erlbaum Associates.

Kağıtçıbaşı, Ç. and Cemalcılar, Z. (2014). Dünden bugüne insan ve insanlar: Sosyal psikolojiye giriş $\left(16^{\text {th }}\right.$ ed.). İstanbul: Evrim Yayınevi.

King, P. M. and Kitchener, K. S. (2004). Reflective judgment: Theory and research on the development of epistemic assumptions through adulthood. Educational Psychologist, 39(1), 5-18.

Kitayama, S., Duffy, S. and Uchida, Y. (2007). Self as cultural mode of being. In S.Kitayama and D. Cohen, (Eds.), Handbook of cultural psychology (pp. 136-174). New York: The Guilford Press.

Koballa, T. R., Glynn, S. M., Upson, L. and Coleman, D. C. (2005). Conceptions of teaching science held by novice teachers in an alternative certification program. Journal of Science Teacher Education, 16, 287-308.

Koballa, T. R, Graber, W., Coleman, D. C. and Kemp, A. C. (2000). Prospective gymnasium teachers' conceptions of chemistry learning and teaching. International Journal of Science Education, 22(2), 209-224.

Marton, F., Dall'Alba, G. and Beaty, E. (1993). Conceptions of learning. International Journal of Educational Research, 19(3), 277-299.

Muis, K. R. (2007). The role of epistemic beliefs in self-regulated learning. Educational Psychologist, 42, 173-190.

Pajares, M. F. (1992). Teachers' beliefs and educational research: Cleaning up a messy construct. Review of Educational Research, 62(3), 307-332. 
Palmer, B. and Marra, R. M. (2008). Individual domain-specific epistemologies: 1mplications for educational practice. In M. S. Khine, (Ed.), Knowing, knowledge and beliefs. epistemological studies across diverse cultures (pp. 325-350). Dordrecht: Springer.

Perry, W. G. (1970). Forms of intellectual and ethical development in the college years: A scheme. New York: Holt, Rinehart and Winston.

Rokeach, M. (1968). Beliefs, attitudes and values. San Francisco: Jossey-Bass Inc.

Saljö, R. (1979). Learning in the learner's perspective: Some commonsense conceptions. Gothenburg, Sweden: Institute of Education, University of Gothenburg.

Schommer, M. (1994). An emerging conceptualization of epistemological beliefs and their role in learning. In R. Garner and P. Alexander, (Eds.), Beliefs about text and about text instruction (pp. 25-39). Hillsdale, NJ: Erlbaum.

Schommer-Aikins, M. (2004). Explaining the epistemological belief system: Introducing the embedded systemic model and coordinated research approach. Educational Psychologist, 39(1),19-29.

Stathopoulou, C. and Vosniadou, S. (2007). Exploring the relationship between physics-related epistemological beliefs and physics understanding. Contemporary Educational Psychology, 32, 255-281.

Triandis, H. C. (1995). Individualism and collectivism. Boulder, Colo.: Westview Press.

Tsai, C. C. (2002). Nested epistemologies: science teachers' beliefs of teaching, learning and science. International Journal of Science Education, 24(8), 771-783.

Tsai, C. C. (2004). Conceptions of learning science among high school students in Taiwan: A phenomenographic analysis. International Journal of Science Education, 26(14), 1733-1750. 
Yılmaz-Tüzün, O. and Topçu, M. S. (2008). Relationships among preservice science teachers' epistemological beliefs, epistemological world views, and self-efficacy beliefs. International Journal of Science Education, 30(1), 65-85. 